Waldemar Szczerbiński

Uniwersytet im. Adama Mickiewicza w Poznaniu heschel@poczta.onet.pl

ORCID: 0000-0003-2946-7352

DOI: http://dx.doi.org/10.12775/BPTh.2019.006
Biblica

et

Patristica

Thoruniensia

12 (2019) 2: 111-127

ISSN (print) 1689-5150

ISSN (online) 2450-7059

\title{
Judaism and Human Sexuality
}

\section{Judaizm wobec seksualności człowieka}

\begin{abstract}
In the Jewish religion the starting point for all reflections on the subject of the body, and also on sexuality, is the biblical image of man as imago Dei. Thus in Judaism there are no forms of duality in which there would be an aporia between the bodily and the spiritual. Judaism teaches that man is primarily created in the image and likeness of God, and at the same time he is by nature a gifted being. As such, he enters into relations both with the Creator and with other human beings. Thus in Judaism there is a connection between human sexuality and the human sociality, and these dimensions, in turn, have their reference to God. Three dimensions of human existence (human sexuality, human sociality, human sanctity) condition each other. The Jewish religion clearly shows that the sphere of the human sexuality has gone through the path of socialization and spiritualization. Halakha - Jewish law regulates the life of a Jew in such detail and in such a way that it is sometimes difficult to distinguish a religious sphere from a secular, a spiritual, a physical, a transcendent and an immanent domain. Everything has its reference to God. In Judaism, the whole man, not only a part of him, is good. The presented article will present the teaching of Judaism on human sexuality in the light of traditional sources of Judaism: the Torah, Talmud and the codices of Jewish law.
\end{abstract}

Streszczenie. Punktem wyjścia w religii żydowskiej dla wszelkich rozważań na temat ciała, a co za tym idzie także seksualności, jest biblijny obraz człowieka jako „imago Dei”. Stąd w judaizmie nie występują jakiekolwiek formy dualizmu, w którym widoczne byłyby aporie między tym, co cielesne, a tym, co duchowe. Judaizm uczy, że człowiek jest przede wszystkim stworzony na obraz i podobieństwo Boga, a przy tym jest z natury bytem obdarzonym określoną płcią. Jako taki wchodzi w relacje zarówno ze Stwórcą, jak i z innymi istotami ludzkimi. Stąd w judaizmie istnieje związek między ludzką seksualnością a ludzką społecznością, a te wymiary z kolei mają swoje odniesienie do Boga. Trzy wymiary ludzkiej egzystencji (human sexuality, human sociality, human sanctity) wzajemnie się warunkują. W religii żydowskiej wyraźnie widać, że sfera płciowa człowieka przeszła drogę uspołecznienia i spirytualizacji. Halacha - prawo żydowskie reguluje życie Żyda tak szczegółowo i w taki sposób, że niekiedy trudno rozgraniczyć dziedzinę religijną od świeckiej, duchową od cielesnej, transcendentną 
od immanentnej. Wszystko ma swoje odniesienie do Boga. W judaizmie cały człowiek, a nie tylko jakaś jego część jest dobra. W prezentowanym artykule zostało ukazane nauczanie judaizmu na temat seksualności człowieka w świetle tradycyjnych źródeł judaizmu: Tory, Talmudu i kodeksów prawa żydowskiego.

Key words: Judaism; human being; body; sex; sexuality; man; woman.

Słowa kluczowe: judaizm; człowiek; ciało; płeć; seksualność; kobieta; mężczyzna.

$\mathrm{H}$ uman sexuality should be interpreted against a broader perspective of understanding human corporeality, which, in turn, is based on a specific anthropological concept. In Judaism, the starting point for all reflections on the subject of man is the Torah, which contains the text about the creation of the world, including the human being: "So God created mankind in his own image, in the image of God he created them; male and female he created them" (Gen 1:27). ${ }^{1}$ This passage clearly indicates the reason for the existence of man and the likeness of both man and woman to the Creator. Masculinity and femininity are an expression of the will of God and are not accidental. A little further, the biblical author describes the way of creation of a woman: "So the LoRD God caused the man to fall into a deep sleep; and while he was sleeping, he took one of the man's ribs and then closed up the place with flesh. Then the LoRD God made a woman from the rib he had taken out of the man, and he brought her to the man. The man said, 'This is now bone of my bones and flesh of my flesh; she shall be called woman, for she was taken out of man' " (Gen 2:21-23). The Hebrew text uses the word "ish" to denote man and "isha" to denote woman. It speaks about the relationship and unity between a woman and a man. In general, both Jewish and Christian comments emphasize that the aforementioned passage proves the equality and dignity of a woman who is in no way inferior to a man. Furthermore, Jewish commentators also reflect why the Creator made a woman out of a rib rather than another part of her body. Midrash tells us that God considered other possibilities, but He rejected them one by one. $\mathrm{He}$ rejected the head, lest the woman be haughty; the eye, lest she see everything; the ear, lest she be an eavesdropper; lips, lest she be a chatter-box; the heart, lest she be jealous; legs, lest she be a run-about; the hand, lest she touch everything. He made a woman from a rib which is deep in the body so that she would be a modest and humble creature. According to the author of the Midrash story,

1 All biblical texts in English come from the New International Version in : https:// www.biblegateway.com/ 
God's plan did not work because a woman possesses all the aforementioned features. ${ }^{2}$

Sometimes negative statements about a woman are intertwined with positive ones. That is even visible in the Bible. In the Book of Ecclesiastes there is a statement: "I find more bitter than death the woman who is a snare, whose heart is a trap and whose hands are chains" (Ecc 7:26). In the Book of Proverbs, on the other hand, there are completely different words: "He who finds a wife finds what is good and receives favor from the LoRD" (Prov 18:22). As we can see, a woman sometimes appears as a curse, another time as a blessing. The majority of Rabbis' statements which the Talmud quotes are positive. They can be summarized as follows: a man without a wife is not a full human being. A woman is somehow a complement to his being. Only together are they true unity, fullness of humanity, Adam. A man without a wife cannot achieve joy, blessing, goodness, reconciliation, peace, and fullness of life. ${ }^{3}$

A certain regularity in Judaism is not without significance, namely all discussions about women are conducted by men. In the classic Jewish sources there are discussions about the qualities of wife, but there is not any reflection about the qualities a good husband should have. Furthermore, even the most favorable views about women are expressed in the context of their relationship with a man. ${ }^{4}$ Sometimes it appears that the sense of a woman's existence depends on how she would complement the life of a man. The text of the Talmud speaks explicitly: "A woman is a golem and she makes a covenant only with one who makes her into a vessel." 5 Golem is a being created from clay in the shape of a human, but deprived of a rational soul. This is a shapeless creature that has no form. A little further, the Talmud adds that this complementation of a woman takes place in a sexual act which is determined by the dominant and active nature of the male element and the submissive and passive nature of the female element.

Every morning a devout Jew recites the following words: "Blessed are You, O God, King of the Universe, who has not made me a woman." 6 The pious

2 See. Bereishit Rabbah 18. All citations from the Talmud come from The Sefaria Library, in: https://www.sefaria.org/texts

3 See. T.B., Yevamot 63a.

4 On the teaching of Judaism about women see P. Podeszwa, W. Szczerbiński, Co warto wiedzieć o judaizmie, Poznań 2018, pp. 61-76.

5 T.B., Sanhedrin 22b.

6 Quoted after M. Rzadkowolska, Kobieta żydowska, kobieta czytająca, p. 2, in: http:// rcin.org.pl/Content/56551/WA248_68659_P-I-2795_rzadkowol-kobieta.pdf (accessed September 12, 2018). 
woman, on the other hand, prays in the morning with her prayer book: "Blessed are You, O God, King of the World, who has created me according to your will." 7 From today's point of view, such a prayer, especially of a man, seems to be a great scandal and meets severe criticism, particularly of the Jewish and non-Jewish feminist groups. According to the rabbinical interpretation, men do not pray in this way to show their contempt or superiority to women. This prayer is accompanied by the conviction that a man is called to worship God more fully and to show his obedience to Him by fulfilling mitzvot (248 positive commandments and 365 negative commandments). Piety is measured by zeal in the practice of the commandments (quantity and quality). Meanwhile, the woman has fewer mitzvot to obey. Only three rules apply to women: kindling candles at the beginning of the Sabbath, separating from her husband during menstruation and cleansing in the mikvah after it ends; sharing challah among household members.

The issue of corporality occupies an important place in the Jewish mentality. ${ }^{8}$ This is not the result of the general contemporary tendency to look at man from the perspective of carnality, but from the biblical conviction that the body created by God is good, necessary and called to sanctity. An important element is the soul which carries an element of the Divine nature and affects the whole person, including the body. In Judaism there is also a belief that the body influences the condition of the soul to a greater extent. Judaism has developed its own understanding of the body and soul, which is a significant element of the creationist concept of man. The conviction of the unity of the body and soul was primitive and was based on the authority of the Torah's Divine origin, which repeatedly shows such unity. ${ }^{9}$ In the Old Testament, there are interchangeable uses of expressions to describe man: the living soul and the living body. The biblical basar is a living body, a body constantly permeated by the soul. Biblical Judaism is thus characterized by anthropological monism.

The body became the subject of Jewish law, which defines, sometimes very scrupulously, how to care for the body in everyday life. Judaism views the body as good and holy because of its origin from God. This worldview model is also inscribed in the needs of the body. Jewish thought appeals for a good interpretation and fulfilling the needs of the body. Life in accordance with the commandments of God and combining these commandments with everyday life

7 Ibidem.

8 The question of corporality has been discussed by W. Szczerbiński, Rozumienie ciała $w$ teologii i filozofii judaizmu, in: Caritas in veritate, M. Antoniewicz (ed.), Poznań 2010, pp. 83-96.

9 For example, Gen 2:7; Ps 103: 29-30. 
is an opportunity for man to sanctify it. Much space in the sphere of Jewish corporeality is devoted to human sexuality. ${ }^{10}$ Sexuality, as an element of human nature, is God's gift. The Jewish thought interprets it even as a task which a person should accept and fulfill.

Judaism teaches that man is primarily created in the image and likeness of God, and at the same time, is inherently a sexual being with an established sex. As such, it enters into relations both with the Creator and with other human beings. David Novak observes that there is a connection between human sexuality and the human community, and these dimensions, in turn, have their relation to God. Three dimensions of human existence (human sexuality, human sociality and human sanctity) condition each other. ${ }^{11}$ In the Jewish religion, it is clear that the human sexuality has gone through the stages of socialization and spiritualization.

Sexuality is perceived as a law of nature because its legitimization is based on the normative order of creation, and not on the established law. This Jewish truth is confirmed in the Talmudic dispute, which concerned the correct interpretation of the biblical command "Be fruitful and increase in number; fill the earth and subdue it" (Gen 1:28). The supporters of Shammai recommend having two sons, while the followers of Hillel advocated having a son and daughter, according to the action of God himself who "created them male and female" (Gen 5:2). The Talmud emphasizes that the reasoning behind Hillel's school refers to the "creation of the world" in which from the beginning the masculine and feminine elements appeared. ${ }^{12}$ The additional order "Be fruitful and increase in number" is treated by the rabbis as recognition of the normative order of creation, and not as an arbitrary recommendation. Thus the Torah confirms this original norm and does not create it from scratch.

10 On the theme on sexuality in Jewish tradition, see D. Biale, Eros: Sex and Body, in: Contemporary Jewish Religious Thought, A.A. Cohen, P. Mendes-Flohr (ed.), New YorkLondon 1988, pp. 177-182; R. Biale, Women and Jewish Law: An Exploration of Women's Issues in Halakhic Sources, New York 1984; L. Epstein, Sex Love and Custom in Judaism, New York 1948; D.M. Feldman, Birth Control in Jewish Law, New York 1968; M. Kaufman, Love, Marriage, and Family in Jewish Law and Tradition, Northvale 1992; M. Lamm, The Jewish Way in Love and Marriage, San Francisco 1980; R. Patai, Sex and family in the Bible and the Middle East, Garden City 1959.

11 See. D. Novak, Some Aspects of Sex, Society, and God in Judaism, in: Contemporary Jewish Ethics and Morality, E.N. Dorf, L.E. Newman (ed.), New York-Oxford 1995, pp. 271288.

12 See. T.B, Yevamot 61b-62a. 
Jewish thinkers emphasize that the text discussed in the Talmud refers to human sexuality in general and not only to the Jewish sexuality. ${ }^{13}$ Sexuality is a universal and fundamental experience which has its roots in the natural order established by the Creator. However, the provisions of the Law are also the work of God, the legal interpretations are conditioned by the social order which was established by people. ${ }^{14}$ According to Halakha, the social order cannot negate the created natural order, and the task of society is to satisfy human needs, not fight with them. For this reason, celibacy is so strongly rejected or even condemned in Judaism. ${ }^{15}$ Furthermore, the Haggadah recognizes the suppression of human sexuality as a harmful and destructive action against a human being. ${ }^{16}$ It should not be ignored or fought against, but properly directed. ${ }^{17}$

Man's task is to meet the needs which are naturally assigned to him. Such a need is both living in society and realizing one's sexuality. According to David Novak, the society, setting its own goals, channels human sexuality and determines the scope of its fulfillment by means of established norms and institutions. ${ }^{18}$ Maimonides emphasized that "what is natural is left to nature, but action is taken against abuses." ${ }^{19}$

The following legal discussion shows how Judaism developed the social process of explaining human sexuality. Rabbi Akiva commenting on the biblical verse: "That is why a man leaves his father and mother and is united to his wife, and they become one flesh" (Gen 2:24), explains: "his father" is referring to his father's wife; "his mother" is referring to his mother literally. "And shall cleave to his wife," but not to a male; such a relationship is not defined as cleaving. "To his wife," but not to the wife of another man. "And they shall be one flesh" indicates that he should marry one of those with whom he can become one flesh, this excludes domesticated and undomesticated animals as they do not become one flesh." ${ }^{20}$ This passage became the basis for exclusion from socially acceptable forms of human sexuality such relationships as incest, homosexual and other impersonal relationships. It seems that the socialization of sexuality has become the foundation of family life. In this way, in Judaism, the family becomes an institution which directs sexuality towards personalist

13 Cf. D. Novak, Some Aspects of Sex, Society, p. 272.

14 See. T.B., Sanhedrin $88 \mathrm{~b}$.

15 See. T.B., Yevamot 63b.

16 See T,B., Sanhedrin 64a.

17 See. T.B., Shabbat 156a.

18 Cf. D. Novak, Some Aspects of Sex, Society, p. 273.

19 M. Maimonides, Guide of the Perplexed, 3,49, Chicago 1963, p. 611.

20 T.B., Sanhedrin 58a. 
and community-forming goals. Using the words of Hegel the family is a "natural ethical community" and "the best reflection of ethical order"21 This leads to the conclusion that social life is based on the biological and sexual order. In their reflections on human sexuality, the rabbis perceive the signs of incest in its original manifestation. "Incest is perceived as a natural phenomenon which has been overcome only because of social benefit." 22 It is worth mentioning the Talmudic text in this context: "The Scripture says: if somebody lived with his sister, the daughter of his father or his mother, and look at her nakedness, and she would look at his nakedness, it is a shameful thing (hesed - Lev 20:17). Rabin Avin stated that it cannot be considered an offense to marry his sister by Cain and marry his sister by Abel. To cite the words, You said, 'The world shall be built on kindness' " (hesed - Ps 89:3). ${ }^{23}$ In the aforementioned text the word hesed appears which is usually translated as "kindness" or "lovingkindness", but here it is used in the opposite meaning as "shameful things" or "crime". This text uses two opposite meanings to express the conviction that what is now shameful at the dawn of humanity was a necessity for reproduction, beginning with siblings. It is confirmed by other Talmudic text: "For what reason did Adam not marry his daughter? So that Cain would marry his sister and they would procreate immediately, as it is stated: 'For I have said: The world shall be built on kindness [hesed]"' (Ps 89:3). ${ }^{24}$ These types of discussions in Judaism refer to the old legend, which says that Cain and Abel were born with twin sisters, which according to the rabbis would explain why the Torah states that "Cain knew his wife" (Gen 4:17). ${ }^{25}$ Such an interpretation of the Torah originates from the belief that the biblical incestuous relationships at this stage were motivated by the wish, and even the necessity of building a large human community, and thus considered to be good.

In a similar way, Judaism explains another case of biblical incest between Lot and his daughters. ${ }^{26}$ It excuses their incest (breaking the accepted custom) in the belief that it is socially necessary: "Our father is old, and there is no man around here to give us children-as is the custom all over the earth. Let's

21 G.W.F. Hegel, Phenomenology of Spirit, Oxford 1977, p. 268.

22 D. Novak, Some Aspects of Sex, Society, p. 274.

23 T.J., Yevamot $11,1$.

24 T.B., Sanhedrin 58b.

25 In general, the Polish translations explain this text as follows: "Cain had a sexual intercourse with his wife." Such a translation is possible because in the ancient (Aramaic) literature the phrase "to know" is used to describe the sexual relationship between a man and a woman.

26 See. T.B., Horayot 10b. 
get our father to drink wine and then sleep with him and preserve our family line through our father" (Gen. 19: 31-32). However, Lot "was not aware of it when she lay down or when she got up" (Gen 19:35). It could be said that Lot's conduct was completely devoid of any awareness of incestuous behavior because he did not know who the person who was the object of satisfying his desire was. The story of Lot and his daughters is a kind of sublimation ${ }^{27}$ of sexuality for social reasons.

Halakha proclaims the absolute prohibition of incest. ${ }^{28}$ It even eliminates a gap in Jewish law which would eventually allow incest in the event of conversion. According to the law, a converted person is treated as a "new born" person. From a legal point of view, it was possible to have sexual relations between close relatives if both or even just one of them were converted. From the moment of conversion, the ties of kinship cease to exist. For this reason, this kind of incest was forbidden, so that the converts could not refer to the law and claim, "We have passed from a higher level of sanctity to a lower one." ${ }^{29}$ In Judaism, the total social condemnation of incest is motivated primarily by social harmfulness. According to Saadia Gaon, the prohibition of incest is dictated by the integrity of the family. Explaining the commandment referring to paternal respect, the medieval Jewish thinker explains the reason for this prohibition: "so that people do not become like animals, and they would not know their father and could not show him gratitude for bringing them up." 30

In Judaism, the reasons for condemning homosexuality are similar to what has been put forward in relation to incest. Homosexuality is considered to be against the family and contrary to procreation. Its intentionality is reduced to pure sensuality. ${ }^{31}$ The Rabbinic tradition has repeatedly emphasized that heterosexuality of human beings is rooted in the originally bisexual human nature. "Rabbi Yirmeya ben Elazar also said: Adam was first created with two faces, one male and the other female. As it is stated He made a woman and brought unto the man." ${ }^{32}$ This motif appears in many Talmudic texts. ${ }^{33}$ One of the Midrashes explains it in the following way: "Rabbi Elazar stated that androgyne (androgy-

27 Sublimation is understood here as the unconscious defense mechanism, which consists in shifting the unacceptable drive to action This mechanism was described by Sigmund Freud.

28 See. G.W.F. Hegel, Phenomenology of Spirit, Oxford 1977.

29 T.B., Yevamot 22a.

30 Saadia Gaon, Book of Beliefs and Opinions, 3,2, New Haven 1948, p. 141.

31 See M. Maimonides, Guide of the Perplexed, 3,49.

32 T.B., Eruvin 18a.

33 See. T.B., Berakhot 61b; Megillah 9a; Ketubot 8a; Sanhedrin 38b. 
nos)... has been created [...] whereas Rabbi Samuel claimed that God had created him with two faces. 'From the rear and the front You encompassed me, and You placed Your pressure upon me." ${ }^{34}$ This concept of primary bisexuality (hermaphroditism), confirmed by modern embryology, was quite common in the ancient world. ${ }^{35}$ A classic example of such a view is the philosophy of Plato. ${ }^{36} \mathrm{In}$ this way, the belief was expressed that human experiencing oneself as a being who constantly searches for his "missing half" is nothing else but an expression of heterosexual desires, because the other half is of a different sex. It is proper to find oneself and join as "one body" which leads to the satisfaction of carnal desire and procreation.

Thus, the rabbinical tradition emphasizes that human sexuality is an expression of the Creator's will and is inscribed in God's creation. This is the reason why Talmudic texts treat homosexuality as a violation of the fundamental truth about man. "Bar Kappara asked Rabbi Yehuda: 'What is the meaning of the word to'va, abomination, used in the Torah to describe homosexual intercourse (see Lev 18:22)? Rabbi Yehuda answered that it means you are straying after it [to'eata bah], i.e. after an atypical mate." ${ }^{37}$ Rabbis strongly emphasize that homosexuality is based on falsehood, whereas any good must have its foundation in the ontological truth.

In traditional Judaism, homosexuality was perceived not only as incompatible with the social interest, but also as incompatible with human nature. Rabbis treat homosexuality as part of the general degradation of Sodom society. The subject of their interpretation is frequently the following Torah text: "They called to Lot, "Where are the men who came to you tonight? Bring them out to us so that we can have sex with them' " (Gen 19:5). The original text instead of using the word "to have sex" uses the verb "to know". However, the meaning is the same as in the Jewish tradition the verb "to know" (yada) is understood as "to know physically" ${ }^{38}$ The Torah said that "the people of Sodom were wicked and were sinning greatly against the LORD" (Gen 13:13). This is the reason why homosexual rape was considered by the rabbis to be one of the most serious sins. In Judaism there was an awareness of consent for homosexual relations in the Greco-Roman world. ${ }^{39}$ In addition, the rabbis were extremely critical of the community, which was in favor of the same-sex sexual relations, or even

Midrash Tehilim 139,5, Sz. Buber, Wilno 1891, p. 265.

See. K.L. Moore, The Developing Human, Philadelphia 1977, p. 228.

See Plato, Symposium (Uczta), Warszawa 2012, pp. 191-192.

T.B., Nedarim 51a.

For further reading: D. Novak, Some Aspects of Sex, Society, p. 276.

See Avoda Zara 18a. 
indulgent towards them. The reason for such a firm position of rabbinic Judaism is based on the social awareness of the harmfulness of this kind of bodily contacts, which obviously affected first the family, and then the entire tribal national and human community. Those who engage in such homosexual practices will be severely punished, as was already the case when it comes to the Flood and the punishment of Sodom. In the Midrash to the Book of Leviticus "Rav Hiyya explained why 'I am the Lord, your God' (Lev 18:3 and 18:4) is repeated twice. I am the One who punished the generation during the Flood and Sodom and Egypt, I will punish in the future everyone in accordance with their deeds. The generation of the Flood was wiped away from the surface of the earth as it was permeated with wrongdoings [shetufin bezenuf]. On behalf of Rabbi Yose, Rabbi Huna said that the generation of the Flood was wiped away from the surface of the earth because they made marriage contracts [gomasiyot] for male and female relationships." ${ }^{\prime 0}$ It seems, therefore, that the rabbis also distinguish between the society in which homosexuality has spread and the society in which it is officially recognized and sanctioned. The latter case is an expression of complete decadence.

Judaism also condemns completely the phenomenon which today we call "zoophilia". In the Talmud, we find the following passage: "Rabbi Elazar explains why Scripture quotes [the words of the first man] 'This is now bone of my bones and flesh of my flesh' (Gen 2:23). This teaches that Adam had intercourse with each animal and beast in his search for his mate and his mind was not at ease until he had intercourse with Eve." ${ }^{11}$ Only Eve was able to make Adam feel full satisfaction and only with Eve could he "become one flesh" (Gen. 2:24). Moreover, the Torah also emphasizes that Eve was the only being with whom Adam could talk. Jewish thinkers stress that communicating with words is a requirement of social life, not of sexual life. ${ }^{42}$

It might be said that in Judaism a social factor determines the understanding of human sexuality. Even monogamy in heterosexual relationships is justified by the requirement of social reciprocity, without which it would not be possible. The recognition of monogamy as the only form of relationship between a man and a woman first required the elimination of concubinage and polygyny understood as marrying multiple wives. Polyandry as a form of polygamy in which a woman takes more than one husband was banned in Judaism from the very beginning. ${ }^{43}$ It should be remembered that in biblical times,

\footnotetext{
40 Leviticus Rabbah 23,9.

41 Yevamot 63a.

42 See. D. Novak, Some Aspects of Sex, Society, p. 277.

43 Zob. Kidushin 2b.
} 
concubinage and polygamy were practiced by the Jews because the Torah did not prohibit them. ${ }^{44}$ The total prohibition of concubinage, treated as prostitution and adultery, originates from the twelfth century and was introduced by Maimonides, who in his decision referred to the historical context: "Before the Torah was given, when a man would meet a woman in the marketplace, and he and she desired, he could give her payment, engage in relations with her wherever they desired, and then depart. Such a woman is referred to as a qedeshah. When the Torah was given, [relations with] a qedeshah became forbidden. [...] Therefore, a person who has relations with a woman for the sake of lust [le-shem zenut], without marrying her [be-lo-qiddushin] should be punished as prescribed by the Torah, because he had relations with a qedeshah." 45 For Maimonides, the key text comes from the Book of Deuteronomy: "No Israeli woman can be a sacred harlot, nor can any Israeli man cultivate sacred prostitution" (Dt 23:18). Even if we assume that a qedesh / qadesh originates from the word qadosh (holy), which would indicate that this text speaks of sacred prostitution in pagan temples, however, for Maimonides there is no difference between "sacral" and "secular" prostitution. ${ }^{46}$ Jewish commentators indicate that Maimonides relies in his arguments on the biblical story of Judah and Tamar from the Book of Genesis (Genesis 38). Tamar, pretending to be a harlot in circumstances which were not associated with worship, is called a qedeshah (38:21). This term is used interchangeably with the expression zonah (38:15), which denotes an ordinary harlot (secular prostitute). Hence, Maimonides had no doubt that apart from a legitimate wife, every other woman is a harlot, with whom all sexual intercourses are considered sinful and forbidden by the Torah. A concubine is simply a woman who becomes only a sexual object. In spite of the great authority that Mamonides enjoys, many Jewish experts of law disagree with his view by stating that "a concubinage, which is different from the legal marriage, is permitted both by Scripture and by the Talmud." ${ }^{47}$ Maimonides's views in this respect differed from other Jewish thinkers' opinions, as he also clearly postulated innovative principles.

44 Lamech appears as the first man in the Bible who married two women (Gen 4:19). Jacob had two wives and two concubines (Gen 29-30). In biblical Judaism the number of wives reflected the prestige of the monarch: "King Solomon, however, loved many foreign women besides Pharaoh's daughter-Moabites, Ammonites, Edomites, Sidonians and Hittites. [...] He had seven hundred wives of royal birth and three hundred concubines" (1 Kings 11:1-3).

45 M. Maimonides, Hilchot Ishut 1,4.

46 See J. Reider, Deuteronomy with Commentary, Philadelphia 1948, p. 217.

47 D. Novak, Some Aspects of Sex, Society, p. 279. 
In traditional Jewish teaching, all aspects of life are ultimately related to God. In what way does man as a sexual and social being realize in himself the "image of God"? The beginning of the Talmudic treatise on the subject of marriage explains: "If we learn that pagans do not have a religious marriage [qiddushin], how is it possible for them to have a religious divorce [gerushin]? On behalf of the Rabbi Ha-Nasi, the old sage from Sepphoris, Rabbi Yehuda ben Pazzi and Rabbi Hanina stated that either they do not have religious divorce or they themselves give it to each other." ${ }^{38}$ Relying on this passage, Maimonides observes that "before the Torah was given, when a man would meet a woman in the marketplace and he and she decided to marry, he would bring her home, conduct relations in private and thus make her his wife. Once the Torah was given, the Jews were commanded that when a man desires to marry a woman, he must acquire her as a wife in the presence of witnesses. [Only] after this, does she become his wife. This is [alluded to in Deuteronomy 22:13]: 'When a man takes a wife and has relations with her. [...]" 49 It would seem that the Torah does not take into account the original reciprocity of man and woman in the initiation of marriage. However, the later form of mutual consent indicates that even if the marriage initiative remained on the part of the man, it required the consent of the woman and reciprocity. It should be emphasized that the Jewish marriage is not only a civil contract, but, above all, a religious covenant, modeled on the Covenant of God with the people of Israel. Marriage understood in this manner required the presence of witnesses, which was emphasized by Maimonides. After receiving the Torah from God, the recognition of marriage was associated with an oath made to God in the presence of witnesses, and not, as before, with sexual consummation - which is a private not a public act. ${ }^{50}$ Witnesses represent the "holy community" to a minimal extent, thus confirming not only the legal fact, but, most importantly, religious fact. ${ }^{51}$ The correct and complete form of the Jewish wedding ritual, during which the name of God is invoked directly, requires the presence of a proper number of people, a quorum of ten. ${ }^{52}$

The presence of God in concluding a Jewish marriage is the subject of inquiry in Haggadic stories. One of them states: "Rabbi Simlai told them [his students]: at the very beginning Adam was created 'from the dust of the ground'

\footnotetext{
48 T.J, Kiddushin 1,1.

49 M. Maimonides, Hilchot Ishut 1,1; Hilchot Melachim 9,8.

50 See. M. Maimonides, Hilchot Ishut 10,2.

51 This aspect of Jewish marriage is explained in detail in: S. Atlas, Netivim Be-Mishpat
} Ha'Ivri, New York 1978, pp. 246-247.

52 See T.B., Ketubot $7 \mathrm{~b}$. 
(Gen 2:7) and Eve was created from a man. After Adam, people (men and women) were created 'in our image, in our likeness' (Gen 1:26). It is impossible that a man lives without a woman and woman without a man; it is also impossible that both of them live without the Divine presence of God (Shekhinah)." ${ }^{33}$ This idea is reflected in the Talmud, which explains that there are three partners in the forming of a person: the Holy One, who provides the soul and his father and his mother." ${ }^{54}$ Thus, God is present not only in the marital community, but also in their fertility. In Judaism, it is clearly visible that the dimensions of sexual and social life are correlated and embedded in the religious dimension. This is the reason why the category of holiness refers not only to the life of the whole Jewish community, but also to the sexual life of the spouses.

Apart from the rabbinic tradition, the Bible is the source of the analogy of a marriage understood as a relationship between a man and a woman and the Covenant understood as a relationship between God and the people of Israel. The basis of both relationships is faithfulness (emunah) ${ }^{55}$ In the Book of Hosea there is the following passage:

"In that day I will make a covenant for them, with the beasts of the field, the birds in the sky and the creatures that move along the ground. [...] I will betroth you to me forever; I will betroth you in righteousness and justice, in love and compassion" (Hos 2:18-21). In the Book of Malachi we can find the following words: "You flood the LoRD's altar with tears. You weep and wail because he no longer looks with favor on your offerings or accepts them with pleasure from your hands. You ask, 'Why?' It is because the LoRD is the witness between you and the wife of your youth. You have been unfaithful to her, though she is your partner, the wife of your marriage covenant" (Mal 2:13-14).

In the rabbinic literature, the classic example of sacred understanding of sexuality is the interpretation of the Song of Songs, which uses the image of marital love between a woman and a man to allegorically express God's love for the people of Israel. ${ }^{56}$ God's love is not so much a model but rather a source of human love. Spouses somehow participate in God's love, which is primary and unlimited. This can be understood in two ways.

53 T.J., Berakhot 9,1/12.

54 T.B., Kiduszin 30b.

55 The Hebrew word emunah denotes faith, justice, righteousness, stability and credibility. This concept has a common stem (aman) with the word emet, which is understood as truth, honesty, correctness. In biblical texts, these two words often appear together, because faith without truth would be meaningless. It might be said that emunah signifies faith in truth.

56 See R. Gordis, The Song of Songs and Lamentations, New York 1974, pp. 1-3. 
For Jewish Kabbalists, the male-female relationship is a symbolic participation in the male-female relationship of the Divine itself. The Zohar ${ }^{57}$ says simply: "Come and see that the desire of a woman by a man and the desire of a man by a woman and their union creates a soul [...] and this earthly desire is contained in God's desire." ${ }^{58}$ The critics of this view emphasize that the Kabbalists violate the pure monotheism of Judaism. Moreover, treating human sexuality only as a symbol of the true reality of God Himself, they neglect the element of human corporeality, which is an important dimension of human sexuality. This approach to human sexuality can lead to negating its value in the physical dimension in favor of the spiritual dimension. ${ }^{59}$ Thus, Jewish mysticism departs quite significantly from the biblical and rabbinical message, which presents love as an act of God's self-transcendence. In Kabbalah, however, God's love remains enclosed in itself, in the reality, to which man has no access in this world.

The other approach is a much more widespread Jewish tradition which claims that sexual love in the marriage covenant is nothing else but a participation in the holy covenant, which is an expression of God's eternal love for His people. In Judaism, sanctified conjugal love is a reflection of the Creators eternal love described in the Deutero-Isaiah: "but with everlasting kindness, I will have compassion on you," says the LORD your Redeemer. [...] Though the mountains be shaken and the hills be removed yet my unfailing love for you will not be shaken nor my covenant of peace be removed, says the LORD, who has compassion on you" (Is 54:8-10). Sexual acts in a Jewish marriage are something more than an expression of mutual love and procreation, accompanied by experiencing bodily pleasure. "It seems wrong to me," observes David Novak, "to recognize bodily pleasure as the essence of sexual love, although it is a sine qua non condition of this act, as in all other bodily pleasures, such as eating, drinking, bathing, we try to see the higher sense of our bodies. [...] In heterosexual love, we seek ecstasy, which is expressed by two Greek words ex histemi, meaning 'to transcend'. In other words, the aim of our sexuality is transcendence, and eros seeks the spirit." 60 It might be said that the real eros somehow tries to go beyond the limitations of the human body. Maimonides argued that in the

57 Zohar (Sefer ha-Zohar - The Book of Radiance/Splendor) - the thirteenth-century mystical commentary on the Torah, the Song of Songs and the Book of Ruth. This is the basic work of Jewish mysticism, which contains texts on the nature of God, the origin and form of the world, soul, sin, redemption, good and evil.

58 Zohar, Lekh-Lekha 1,85 b.

59 See. R.J.Z. Werblowsky, Jeseph Karo: Lawyer and Mistic, Oxford 1962, p. 137.

60 D. Novak, Some Aspects of Sex, Society, p. 282. 
sexual act we overcome the immanence of our bodies which limit our souls. ${ }^{61}$ The sexual act is short-lived, and after it the finite and deadly body returns to its previous state. The Haggadah teaches: "David said before God, 'my father Jesse did not intend to beget me, but he was guided only by his own pleasure. You know that it is so because after their mutual satisfaction, he turned his face and she turned her face and You united the drops." 62

In a sense, sexuality allows the human body to transcend finiteness and mortality. As incarnate souls, we can transcend ourselves through carnal acts because we are not angels, but only people of flesh and blood. ${ }^{63}$ Therefore, periodic separation (niddah) associated with menstruation of the woman, which is imposed by Jewish law, is perceived as the perfecting of the erotic relationship, which is more than a bodily act. "Undying love" is not a figment of poetic imagination, but a desire inscribed in human nature. Sexual desire is an expression of the desire to immortalize human existence. In Judaism there is a belief that this desire is rooted in God's eternal love for His people. This consciousness enables men to overcome their selfish love and to act creatively. It is confirmed by the rabbinic interpretations of the Song of Songs, in which there are the following words: "for love is as strong as death [azah ke-mavet], its jealousy unyielding as the grave. It burns like blazing fire, like a mighty flame" (Song 8:6). It seems that in this passage the word "death" is used in the sense of "perfection" or "fullness" because it is the most moving experience which is the limit of human cognitive abilities. Generally, love appears to be as strong as finite in this world. However, the rabbis try to prove that love is stronger than death. Using this interpretation, the word ke-mavet (like/as death) is interpreted as ke-mot (this is like) and then the question arises: like what? The answer can be found in Shir ha-Shirim: 64 "For love is as strong as [ke-mot] death, which God has for you, says the Scripture, 'I have loved you, says the Lord' (Mal 1:2). Jealousy is as sad as grave - this refers to the period when the Lord was jealous of idolatry [avodah zarah], as we can read: 'They made him jealous with their foreign gods' (Dt 32:16). [...] Another interpretation: 'For love is as strong as death' this is love of a man to a woman as it was said: 'Enjoy life with your wife, whom you love' (Ecc 9:9) [...] her shine is the fiery shine, the lantern of God. Rabbi

61 See. M. Maimonides, Hilchot Yesodei Ha-Torah, 1,7.

62 Vayikra Rabbah 14,5.

63 See. T.B., Kidushin 54a.

64 Shir ha-Shirim Rabbah - is a Haggadic Midrash to the Song of Songs which was also cited by Rashi (Cant. VII, 11). It is sometimes called Haggadah Hazita or Midrash Hazita. See the English translation https://www.sefaria.org/Shir_HaShirim_Rabbah?lang=bi (accessed March 7, 2019). 
Berachia said that love is as heavenly fire which is neither destroyed nor extinguished by water." ${ }^{35}$

The history of Jewish thought on sexuality is complex and marked by deep tensions. Many of these tensions have been present from the beginning in the primary source of Judaism, the Hebrew Bible. Stories (e.g. the history of Ruth) are not consistent with the rigors of Jewish law; sexual offenses (e.g. David's adultery) are justified by God's plan for Israel, sexual desires are subordinate to the good of the community (although not in the Song of Songs). The tensions of the biblical period did not disappear in the Talmudic writings of the rabbis, although attempts were made to alleviate them. Although in all varieties of Judaism the attitude to sexuality was rather positive, it was never devoid of ambivalence. The bodily desire is considered by the Jewish tradition as a gift from God, a natural part of human life, indispensable for demographic survival. However, this desire is, on the one hand, participation in the Divine itself, on the other hand, yielding to one's pleasure in the absence of self-control. In Judaism, sexuality is an integral part of marriage and fertility, and thus acquires a religious character.

Jewish sexual ethics is related to the religious order of marriage. God's call to marry entails the duty of procreation and establishes a patriarchal model of marriage and family. In Judaism, these two elements, the duty of procreation and its patriarchal context have a significant impact on specific legal provisions regarding sexual acts and the ethical comments which have constantly accompanied them.

In the Jewish tradition, there are different approaches to human sexuality. "While some writers sanctioned sexuality only for procreative purposes, others, considering the dominant positions of Halakha, perceived eroticism positively, even if it was motivated solely by the desire for pleasure. The characteristic feature of all approaches is that they never give suggestions for abandoning sexual life altogether." ${ }^{6}$ The aforementioned analysis allows us to state that in Judaism, human sexuality, historically socialized and sanctified in the marriage covenant, becomes for a man and woman a manner of affirming the love of God who never dies.

65 Shir ha-Shirim Rabbah 8,6.

66 D. Biale, Eros: Sex and Body, p. 181. 


\section{Bibliography}

Atlas S., Netivim Be-Mishpat Ha'Ivri, New York 1978.

Biale D. "Eros: Sex and Body," in: Contemporary Jewish Religious Thought, A.A. Cohen,

P. Mendes-Flohr (eds.), New York-London 1988, pp. 177-182.

Biale R., Women and Jewish Law: An Exploration of Women's Issues in Halakhic Sources, New York 1984.

Epstein L., Sex Love and Custom in Judaism, New York 1948.

Feldman D.M., Birth Control in Jewish Law, New York 1968.

Gordis R., The Song of Songs and Lamentations, New York 1974.

Hegel G.W.F., Phenomenology of Spirit, Oxford 1977.

Kaufman M., Love, Marriage, and Family in Jewish Law and Tradition, Northvale 1992.

Lamm M., The Jewish Way in Love and Marriage, San Francisco 1980.

Majmonides M., Guide of the Perplexed, 3,49, Chicago 1963.

Moore K.L., The Developing Human, Philadelphia 1977.

Patai R., Sex and Family in the Bible and the Middle East, Garden City 1959.

Pismo Święte Starego i Nowego Testamentu, Edycja Świętego Pawła, Częstochowa 2009. Platon, Uczta, Warszawa 2012.

Podeszwa P., Szczerbiński W., Co warto wiedzieć o judaizmie, Poznań 2018.

Reider J, Deuteronomy with Commentary, Philadelphia 1948.

Rzadkowolska M., Kobieta żydowska, kobieta czytająca, p. 2, in: http://rcin.org.pl/Content/56551/WA248_68659_P-I-2795_rzadkowol-kobieta.pdf (accessed September 12, 2018).

Szczerbiński W., "Rozumienie ciała w teologii i filozofii judaizmu," in: Caritas in veritate, M. Antoniewicz (ed.), Poznań 2010, pp. 83-96.

Talmud, The Sefaria Library in: https://www.sefaria.org/texts

Werblowsky R.J.Z., Jeseph Karo: Lawyer and Mistic, Oxford 1962. 